\title{
Recycling brownfields? The influence of on-site contamination on home buyers
}

\author{
K. Winson-Geideman \\ Department of Landscape Architecture and Urban Planning, \\ Texas A\&M University, USA
}

\begin{abstract}
This research uses contingent valuation (CV) to assess home buyer perceptions regarding housing built on formerly contaminated sites. Respondents are questioned about the underlying stigma associated with past contamination and willingness to purchase a home built on a brownfield. Discounts and market loss in Chicago, Illinois, a metropolitan area characterized by a large number of brownfields and an active housing market, are identified and analyzed.
\end{abstract}

Keywords: brownfields, contingent valuation, stigma.

\section{Introduction}

Over the past 50 years, tens of thousands of the factories, warehouses, rail yards, and other facilities that stimulated industrial growth in many parts of the world have been abandoned. Buildings became obsolete as innovation required the use of new technologies and companies moved to new locations. Many of these facilities were in use before there was significant regulation of hazardous substances, and quite often are now impacted by residual contamination though the type and extent is unknown. Many times the party responsible for the contamination is no longer in existence.

The high number of these sites, known as brownfields, and the associated threats due to contamination often result in negative impacts on property value and greater risk for property investment. While a substantial amount of research addresses value and liquidity issues when these sites are returned to industrial use or reclaimed for commercial purposes, in general, there are few studies that address the demand for residential use, or how individual homeowners might integrate knowledge of contamination into location decisions. 
Prior research conducted by the same author shows evidence that current disclosure methods, typically deed restrictions, do not provide sufficient notice to individual consumers about contamination, use restrictions, or maintenance procedures associated with remediated property [1]. Individuals typically have little knowledge of the potential threats to health and financial investments while businesses and public institutions employ a bevy of legal and scientific professionals to determine the risk of owning and redeveloping brownfields. If maintenance procedures are then neglected, containment measures are rendered ineffective making human exposure to potentially toxic chemicals much more likely.

The purpose of this study is to evaluate the impact of contamination on the location decision of potential home buyers, specifically where the home is built on a site that has completed a state-sponsored, brownfield cleanup program. Contingent valuation is used to estimate the perceived risk associated with such sites.

\section{Literature}

Shifting economic conditions and other factors, have forced many states and municipalities to rethink their approach to brownfields. Many times, advances in transportation and policy changes have made the sites no longer viable for industrial development. Some find new life as commercial/retail or industrial developments, but others are poorly situated for such use due to size, location and other factors. Past U.S. brownfield policy has been directed to economic development and has thus ignored the potential of converting sites into housing, even though in some situations this is the highest and best use.

More recent trends, however, show that state Voluntary Clean-up Programs (VCPs) are beginning to actively encourage redevelopment for residential use. Since many of these sites are located in easily accessible, urban areas within close proximity to entertainment, educational opportunities, and infrastructure, it is a reasonable and logical use. In a report released in 2000, 5,200 units of housing had been built on brownfields in California, and 2,855 and 1,400 were constructed in Colorado and Michigan, respectively [2].

Given that, a certain degree of residual risk or "stigma" is likely to remain on sites that are subject to past contamination issues or containment measures. Typically the stigma surrounding a contaminated site is greater prior to cleanup, although residual stigma may remain, manifest in failed or discounted transactions. Mundy classifies the consequences of stigma into two areas: direct and indirect [3]. While increasing incidence of cancer or decreased occupancy in an apartment building exemplifies direct effects, the exodus of residents from an effected area, such as the Love Canal in New York is an example of an indirect effect.

Studies show that knowledge of contamination and residual stigma negatively impact property markets. In a study of the impacts of PCB contamination on property values in Anniston, Alabama, Simons found $95 \%$ of potential bidders were unwilling to bid on contaminated property [4]. Simons, Winson, and 
Mikelbank note that an oil spill on the Patuxent River in Maryland increased market time for properties by 40\% [5]. McCluskey and Rausser [6] found that increased information from media coverage affected property sales. Additionally, the reluctance of lenders to provide funding for remediated sites may impact the number of bidders [7].

This study uses contingent valuation to assess the discount and number of failed transactions associated with residual stigma caused by contamination. It is anticipated that if home buyers are informed of prior contamination before a purchase contract is executed, they will either discount the transaction based on their perception of risk or they will withdraw from the market altogether.

\section{Methodology}

Within the past ten years, contingent valuation has become an important tool in the valuation of environmental damages for market goods. Originally used to value non-market goods, particularly natural resources, it involves the use of formal surveys of market participants to determine willingness to pay or accept compensation for damages. When used to evaluate the impact on market goods, the same survey methodology is used, but the discount associated with damages and the willingness to bid of the respondents are the best methods of measurement.

Simons [4] recognizes that $\mathrm{CV}$ can provide guidance when valuing contaminated property. The author recommends the use of two moderately rigorous techniques, rather than a single strong one when data permits. Chalmers and Roehr [8], Syms [9] and McLean and Mundy [10] all recommend the use of $\mathrm{CV}$, though the former suggest it be used in concert with the results of a regression analysis (within a hedonic pricing framework). The results of the regression can then be used to verify the findings from the contingent valuation analysis.

\subsection{Survey instrument}

The survey instrument and methodology focuses on gauging a respondent's willingness to bid on a remediated site and any discount that may be associated with that bid. It adopts the survey and CV methodology used by Simons [4] in a case study of PCB contamination in Anniston, Alabama [11].

The first section of the survey is designed to acclimate the respondent to the survey's subject and to the scale used to measure responses $(-3$ to +3 with 0 as neutral). A question is included that establishes the value of the respondent's current home which is used as a baseline response to evaluate any discount associated with contamination.

The second section contains questions that place the respondent's current home in a broader context with three scenarios that may also be interpreted as environmental disamenities. All describe the respondent's current home, yet place it within direct proximity to different types of environmental disamenities: one block from a business park; adjacent to a recently remodeled, operating 
attractive gasoline service station with leaking underground storage tanks (LUST); and an on-site deed restriction limiting ground water use and requiring a building to stay in place as a permanent cap over contamination. Respondents are then asked to value the property given the changes indicated in the scenario.

The last scenario serves as the primary source for data on the stated preferences of the respondents regarding purchasing a home on remediated property. The scenario is replicated from the deed of a property in Chicago that was redeveloped residentially and indicates the home was "part of a state mandated environmental clean-up program. To successfully complete the program, several feet of soil had to be removed from the site and replaced with clean soil. Public record now shows that it has been cleaned to residential standards and is suitable for humans to live on, although there is a restriction indicating that the building must remain over the formerly contaminated portion as a permanent cap. This restriction is a part of the deed and will be passed on in perpetuity."

The questionnaire was administered by telephone and 74 responses were gathered. Three surveyors collected the information over several months in 2002. The surveyors were instructed not to supply information or opinions to the respondents beyond what was included in actual instrument. One survey was omitted from the final analysis because the administrator failed to collect proper data.

\subsection{Measurement techniques}

Two factors are important when evaluating the descriptive results of contingent valuation. First, the portion of respondents willing to bid on a scenario is reflective of market demand. Willingness to bid is indicated by a response to the relative contamination scenario that is greater than $\$ 0$. If the respondent answers $\$ 0$, it is assumed that he or she is unwilling to bid indicating a loss in a market participant. In the event the respondent states a value greater than $\$ 0$, he or she is considered willing to bid, thus showing a willingness to participate in the market for remediated land.

Second, the ratio of maximum bid to the baseline case value reflects the percentage discount of those that did bid. This number is calculated as one minus the percentage discount in price. For example, if the respondent's baseline price is $\$ 100,000$ and the maximum they are willing to bid is $\$ 40,000$, a $60 \%$ discount is reflected [4]. This creates an assessment of consumer risk perception by assigning a dollar value and hence a percent change in the price of property due to contamination.

\section{Results}

The bidders from each of the scenarios were divided into those that were willing to bid (the average bidder), those who bid in the top half of all bidders (top half) and those that bid in the top quarter of all bidders (top quarter). To determine which bidders comprise the top half, the bidders were categorized based on the 
percentage discount of their bid. The total number of bidders was divided in half based on the bid discount. The portion with the lowest bid discount became the top half. Top half bidders were divided the same way to produce the top quarter of all bidders. This is done to control for those bids that are so small that a reasonable seller would be unwilling to accept them.

In the business park scenario, a majority of the respondents indicated a willingness to bid. The respondents appeared to consider that scenario the least detrimental, with an overall bid percentage of $70 \%$ (51 bidders) with an error rate of $+/-7.59 \%$. The average discount of all bidders was $18 \%$.

Interestingly, the top quarter of the bidders were willing to pay a $5 \%$ premium for property within one block of the business park. This may indicate that some buyers are willing to pay a premium to live close to potential employment, but not directly adjacent to it. Yet these numbers are somewhat suspect, given that three participants responded with particularly high premiums. When removed from the calculations, the top quarter shows a $1 \%$ premium. The responses to the business park scenario are listed in Table 1.

Table 1: $\quad$ Descriptive measurements of business park scenario.

\begin{tabular}{|l|c|c|c|c|}
\hline & $\begin{array}{c}\text { Number of } \\
\text { Responses }\end{array}$ & $\begin{array}{c}\text { Number of } \\
\text { bidders }\end{array}$ & $\begin{array}{c}\text { Bid } \\
\text { Percent }\end{array}$ & $\begin{array}{c}\text { Average } \\
\text { Discount }\end{array}$ \\
\hline Average & 73 & 51 & $70 \%$ & $-18 \%$ \\
\hline Top Half & 37 & 26 & $35 \%$ & $-1 \%$ \\
\hline Top Quarter & 19 & 13 & $17 \%$ & $5 \%$ \\
\hline
\end{tabular}

Of those that bid, the LUST scenario was widely considered to be the most debilitating with only 11 of the $73(15 \%)$ respondents choosing to bid on property adjacent to a site with leaking underground storage tanks. The average discount on this scenario was $52 \%$ with an error rate of $+/-27.42 \%$. The top half of the respondents discounted the property value by $31 \%$ and the top quarter of the bidders discounted it by $14 \%$. There were no premium bids for this scenario and every bidder indicated a discounted value. These results are consistent with similar research conducted by Simons and Winson-Geideman [12]. The responses are summarized in Table 2.

Table 2: $\quad$ Descriptive measurements of LUST scenario.

\begin{tabular}{|l|c|c|c|c|}
\hline & $\begin{array}{c}\text { Number of } \\
\text { Responses }\end{array}$ & $\begin{array}{c}\text { Number of } \\
\text { bidders }\end{array}$ & $\begin{array}{c}\text { Bid } \\
\text { Percent }\end{array}$ & $\begin{array}{c}\text { Average } \\
\text { Discount }\end{array}$ \\
\hline & & & & \\
\hline Average & 73 & 11 & $15 \%$ & $-52 \%$ \\
\hline Top Half & 37 & 6 & $8 \%$ & $-31 \%$ \\
\hline Top Quarter & 19 & 3 & $4 \%$ & $-14 \%$ \\
\hline
\end{tabular}


The final scenario reflects the impact of deed restriction associated with prior contamination on bidding and value. Results show a bid percentage of $38 \%$ with an error rate of $\pm 14.64 \%$ at a $95 \%$ level of confidence, indicating that subsequent responses to the same survey question will be within $\pm 14.64 \%$ of what is indicated. The responses fell into the mid-range of perceived disamenities. The average bidder indicated a discount of 39\%. The top half and top quarter bid discounts of $15 \%$ and $10 \%$, respectively. The results for the deed restriction scenario are in Table 3.

Table 3: $\quad$ Descriptive measurements of deed restriction scenario.

\begin{tabular}{|l|c|c|c|c|}
\hline & $\begin{array}{c}\text { Number of } \\
\text { Responses }\end{array}$ & $\begin{array}{c}\text { Number of } \\
\text { bidders }\end{array}$ & $\begin{array}{c}\text { Bid } \\
\text { Percent }\end{array}$ & $\begin{array}{c}\text { Average } \\
\text { Discount }\end{array}$ \\
\hline & & & & \\
\hline Average & 73 & 28 & $38 \%$ & $-39 \%$ \\
\hline Top Half & 37 & 14 & $19 \%$ & $-15 \%$ \\
\hline Top Quarter & 19 & 7 & $10 \%$ & $-10 \%$ \\
\hline
\end{tabular}

\section{Conclusions}

The results of the contingent valuation study show three different discount levels derived from the data that was collected. The average bidder shows a discount of $39 \%$, followed by the top half of bidders with a $15 \%$ discount and the top quarter with a $10 \%$ discount. The bids are calculated in this manner to control for "bottom feeders" or bidders with such extreme discounts that it is unlikely that a rational seller would accept such a bid. For instance, the overall average includes "bottom feeding" discounts as large as $95 \%$.

The level of discount that would most likely be reflected in the actual market falls between the top half and the top quarter discounts of $15 \%$ and $10 \%$, respectively. This level was chosen for three reasons. First, it most closely reflects market studies using multiple regression that quantify the residual effects of contamination on nearby property values. Simons found that uncontaminated, easement-holding properties within two miles of a petroleum pipeline rupture experienced a loss in value of 4-5\% [13]. Nelson, Genereux and Genereux found a reduction in the sale price of homes near a landfill of 6-12\% depending on distance [14]. While these studies are focused on proximity to contamination, it is likely that homes built directly on a contaminated site will experience a slightly higher discount.

Second, the site described in the scenario is low-risk. Careful review shows that the site had been cleaned to residential standards and the dirty soil was removed. Further, any residual contamination is encapsulated by the building minimizing risk of exposure. 
Finally, the site had completed a state-mandated environmental cleanup program and the remaining problem is the residual stigma associated with the history of contamination. This leads to the assumption that similar sites have market potential, and property values remain largely intact although some discount can be expected.

The number of bidders affected by the existence of prior contamination shows a decrease in market demand of $62 \%$. Just over one-third $(38 \%)$ of the respondents were willing to bid on the deed restriction scenario. Although the market loss is less than in Greenberg and colleagues' study (14\%), the results emphasizes the pervasiveness and consistency of the stigma associated with brownfields [15]. Given that, it is likely that buyers will become more willing to purchase brownfield housing as they become more educated about the risks and how they are best minimized.

\section{References}

[1] Winson-Geideman, K. Environmental case studies: ensuring suitable comparables." The Appraisal Journal, 73(3), pp. 53-61, 2005.

[2] Bartsch, C. and Dorfman, B., Brownfields and housing: how are state VCPs encouraging residential development? Northeast-Midwest Institute, 2000.

[3] Mundy B., Valuing Brownfields (Chapter 6). Brownfields: a comprehensive guide to redeveloping contaminated property, eds. Davis, T. and K. Margolis, American Bar Association: Chicago, 1997.

[4] Simons, R., Estimating proximate property damage from PCB contamination in a rural market: a multiple techniques approach. The Appraisal Journal, 70(4), pp: 388-400, 2002.

[5] Simons, R., Winson, K. and Mikelbank, B., The effects of an oil pipeline rupture on single-family house prices. The Appraisal Journal, 69(4), pp: 410-418, 2001.

[6] McCluskey, J. and Rausser, G., Estimation of perceived risk and its effect on property values. Land Economics, 77(1), pp: 42-55, 2001.

[7] Jackson, T. Environmental risk perceptions of lenders and investors in commercial and industrial real estate. Paper presented at The Sixteenth American Real Estate Society Conference, Santa Barbara, California, March 28 to April 1, 2000.

[8] Chalmers, J. and Roehr, S., Issues in the valuation of contaminated property. The Appraisal Journal, 61(1), pp. 28-41, 1993.

[9] Syms, P. The redevelopment of contaminated land for housing use. Joseph Rowntree Foundation: London, 1997.

[10] McClean, D. G. and Mundy, B., Adding contingent valuation and conjoint analysis to the required body of knowledge for the estimation of environmental damages to real property. Journal of Real Estate Practice and Education, 1(1), pp. 1-12, 1998.

[11] The survey is based on an instrument developed by Barton Smith, $\mathrm{PhD}$, University of Houston Department of Economics and adapted by Robert 
A. Simons, PhD, Cleveland State University Department of Urban Affairs.

[12] Simons, R. A. \& Winson-Geideman, K., Determining market perceptions on contamination of residential property buyers using contingent valuation surveys. Journal of Real Estate Research, 27(2), pp. 193-220, 2005.

[13] Simons, R., The effect of pipeline ruptures on non-contaminated residential easement holding property in Fairfax County. The Appraisal Journal, 67(3), pp. 255-63, 1999.

[14] Nelson, A. C., Genereux, J. and Genereux, M., Price effects of landfills on house values. Land Economics, 80(4), pp. 359-65, 1993.

[15] Greenberg, M., Craighill, P., Mayer, H., Zukin, C., \& Wells, J., Brownfield redevelopment and affordable housing: a case study of New Jersey. Housing Policy Debate, 12(3), pp. 515-540, 2001. 